Article

\title{
Small and Medium-Sized Enterprises (SMEs): The Engine of Economic Growth through Investments and Innovation
}

\author{
Ștefan Cristian Gherghina ${ }^{1, *(1)}$, Mihai Alexandru Botezatu ${ }^{2}$, Alexandra Hosszu ${ }^{3}$ and \\ Liliana Nicoleta Simionescu ${ }^{1}$ (D) \\ 1 Department of Finance, The Bucharest University of Economic Studies, 6 Piata Romana, 010374 Bucharest, \\ Romania; liliana.simionescu@fin.ase.ro \\ 2 Department of Informatics, Statistics and Mathematics, School of Computer Science for Business \\ Management, Romanian-American University, 1B Expozitiei Blvd, 1st District, 012101 Bucharest, Romania; \\ mihaibotezatu@gmail.com \\ 3 Doctoral School of Sociology, University of Bucharest, 36-46 Mihail Kogălniceanu Blvd, 050107 Bucharest, \\ Romania; alexandra.hosszu@sas.unibuc.ro \\ * Correspondence: stefan.gherghina@fin.ase.ro; Tel.: +40-741-140-737
}

Received: 16 November 2019; Accepted: 23 December 2019; Published: 1 January 2020

check for updates

\begin{abstract}
Small and medium-sized enterprises (SMEs) are crucial for local economic development, playing a noteworthy role in job creation, poverty alleviation and economic growth, but they encounter many funding barriers. The purpose of the current paper is to investigate the impact of investments and innovation on territorial economic growth, as measured by turnover, for Romanian active enterprises, especially SMEs, over the period 2009-2017. By estimating several log-log linear regressions, the quantitative outcomes provide support for a positive influence of investments on turnover. The association was confirmed both for all active enterprises at the national level, as well as for micro, small, middle-sized and big companies. As regards expenditures on innovation, a positive impact on turnover was acknowledged for all enterprises and particularly for big companies, but there was an absence of any statistically significant relation in the case of SMEs. The impact of firm size on turnover was positive for all active enterprises at the national level, along with active micro-units. Also, the estimation results show a positive impact of the number of active micro-units on territorial economic growth. The empirical findings are relevant to managers and policymakers in order to stimulate, encourage and offer support to SMEs' development through their strategies.
\end{abstract}

Keywords: SMEs; turnover; investments; innovation; competitiveness; regression analysis

\section{Introduction}

Small and medium enterprises (SMEs) are a noteworthy driver of economic development [1], being vital to most economies across the world, particularly in developing and emerging nations [2]. They represent $99 \%$ of all businesses in the European Union (EU) and in the last five years, provided about $85 \%$ of new jobs, also ensuring two-thirds of the total private sector engagement in the region [3]. For instance, in 2015, there were about 23 million SMEs that provided 90 million jobs, generating a higher added value of 3.9 billion EUR [4]. Different to large corporations, SMEs are highly flexible, revealing a superior flexibility to technical shifts, higher promotion of income distribution and better adaptability to fluctuations in the market and new customer requirements, while their organizational structure allows for quicker decision making [5]. Nevertheless, to achieve this potential, SMEs need a continued source of longstanding funding so as to invest in growth opportunities [6]. Hence, wishing to strengthen the entrepreneurial spirit in Europe and to create conditions for the practical development of innovative 
concepts, the European Commission designed a set of measures alongside a modern and coherent policy for SMEs. The main purpose of this plan is to support the growth and development of SMEs in close relation to the employment market [7]. SMEs are viewed as the backbone of an economy [8] since they exert a significant role in lessening poverty, employment creation, foreign trade promotion and technique innovation [9], also contributing meaningfully to the growth of developing economies [10]. So, the strategy adopted in 2008 for Europe via the "Small Business Act" considers the application of the principle "First, think at a small scale" [11] regarding the adoption of policies, regulations and policy measures that should offer support to the needs of SMEs. Since 2010, the European Parliament has adopted a series of resolutions, such as: community policy to stimulate innovation through European SMEs [12], industrial policy for globalization conditions [13], the competitiveness issue and the issue of business opportunities in the European Union [14], the re-industrialization of the economy to provide competitiveness and sustainability [15], supporting information and communications technology (ICT) development regarding the transition towards a type of sustainable economy and the resolution of social and ecological problems mentioned in the European Strategy 2020 [16], easy access for SMEs towards financing possibilities [17] and the stimulation of research/development and innovation processes offered by the research program Horizon 2020 [18,19]. Thus, through European and national policies, and through start-up financing programs or business incubators, SMEs have been encouraged and stimulated to develop, grow and support the economy and local, regional and national activities within communities.

Since markets have become gradually more competitive, SMEs attempt to assert themselves via new product advances in order to compete with large enterprises. Hence, innovation plays a fundamental role in accomplishing competitive power [20], being oriented towards novel products, original marketing and management methods, as well as genuine technologies [21]. The model of Porter [22,23] promotes the idea that enterprises belong to a greater globalization and internationalization process. Competitive advantage is created and supported locally within a national or regional area, each having its own economic or cultural characteristics. The European Commission defines a competitive region as one that is able to "ensure both the number and the quality of jobs" [24]. Regarding this description, the gross domestic product (GDP)/inhabitant is considered to be a proper representation. It can be deconstructed into more components with precise economic interpretations [25].

The idiom "regional competitiveness" is a phrase that refers neither to macroeconomy nor to microeconomy because regions can be considered neither simple accumulations of enterprises from a certain area, nor reductions of a certain nation to a smaller scale. Therefore, it can be considered that the regional level is much more complex and challenging to analyze. Regions are in direct competition with each other for the conquest of markets and for attracting investments [26]. Hence, one region may possess absolute competitive advantages if these include technological and social factors concerning infrastructure or superior institutional factors compared with other regions, which are external to enterprises, but which contribute to their development and greater success.

This paper aims to investigate the role of active enterprises, especially SMEs, in territorial development in Romania, as measured by their turnover. Previous studies on SMEs' access to finance and their innovative capacity have focused on various states such as Albania [27], Brazil [28], Poland [29-32], Romania [21,33-38], Spain [5,39], Malaysia [40], Middle Eastern and Central Asian states [41], Nigeria [1], Portugal [42], United States [43], Vietnam [44] and Zimbabwe [45]. Nevertheless, preceding research for the Romanian case has focused on topics such as the involvement of SMEs in economic growth [38], the role of SMEs in improving employment [37], SMEs' financing options [36], the influence of globalization on SMEs [35], the sustainability of SMEs [33] as well as their importance [34] or innovative capacity [21]. Our research contributes to the existing literature in a number of ways. First, we focus on SMEs in the context of an upper-middle-income nation. The fruitful evolution of central and eastern European nations from planned economies to market-oriented economies would not have been feasible without the enlarged number of SMEs [30]. Studies of this type are rare due to the predilection for exploring firms that are larger, more productive and more capital intensive [44]. 
However, another particularity is that most developing markets feature a bank-based formal financial system with frail equity and debt markets [46], alongside a lack of innovation management experience and state-of-the-art technology [47]. Due to the inheritances of central planning, the growth of SMEs is severely inhibited by their restricted access to finance [48]. Second, the paper advances the literature by providing empirical evidence for the impact of investments and expenditures related to innovation on territorial development in Romania, which to the best of our knowledge has not been explored previously.

The paper is structured as follows. Section 2 examines the previous literature and establishes the research hypotheses, while Section 3 is dedicated to the empirical framework. Section 4 outlines and discusses the quantitative outcomes. The last section provides final remarks and policy implications.

\section{Theoretical Backgrounds, Literature Review and Hypotheses Development}

\subsection{Prior Research on SMEs Financing}

SMEs play an ever more imperative role towards market evolution locally and overseas, influencing sustainable growth in the trading, production and service areas via attracting investments [31]. According to Kersten, et al. [49], SMEs funding plans reveals a positive significant effect on the total volume of financing and/or investment, firm performance and employment. With reference to the theories that enlighten the factors driving firm investment, the acceleration principle theory [50] postulates that companies increase their investments during satisfactory stages of economic growth, whilst investments are reduced during economic recession. According to neoclassical theory [51], firms increase investment if sales increase, but investment diminishes if sales fall.

SMEs are oriented towards profit maximization rather than expansion since their legal status is commonly proprietorship or partnership, these companies being ruled by the resolutions of owners. Owners employ their own assets to fund their businesses, considering profits more vital than investments [52]. Wellalage and Fernandez [46] documented that having formal finance is positively related to firm-level product innovation and process innovation. However, SMEs are challenged with serious financial limitations when compared to listed firms since they cannot increase funds by issuing stocks and bonds, thus bank borrowing is the core source of funding [53]. Besides, scarce collateral, weak solvency, short/no credit history, immature bank-borrower dealings, high transaction costs and information asymmetry were noticed as the main difficulties with reference to gathering commercial bank financing, particularly long-term borrowings [43]. Wang [54] exhibited the most significant impediments observed by SMEs managers, namely "access to finance", "tax rate", "competition", "electricity" and "political factors".

Ullah [48] noticed that SMEs encounter lesser financial restraints in nations with higher levels of GDP per capita, stock market development, legal systems and property rights, besides reduced levels of corruption. Motta and Sharma [28] confirmed that firm size may affect access to capital in the hospitality SME sector as small-sized companies may not own high-quality projects required to acquire bank credits from financial intermediaries. In this vein, Jackowicz and Kozlowski [32] proposed that social ties amongst SMEs managers and bank employees may enhance SMEs' access to bank financing and rouse their investments.

Hypothesis 1a. The turnover of all active enterprises at the national level is determined by the investments performed by these firms and their numbers of employees.

Hypothesis $\mathbf{1 b}$. The turnover of all active companies at the national level is driven by the gross investments performed by these enterprises.

Hypothesis 1c. The turnover of all active firms at the national level is determined by the gross investments performed by these companies, investigated according to business size. 
Hypothesis 1d. The turnover of all the micro-enterprises at the national level is driven by the net investments performed by these companies, the number of active micro-units and the number of employees.

\subsection{Previous Studies on Innovation in SMEs}

In a globalized era-a society based on knowledge, respectively-the SMEs reveal exclusive competitive returns on the strength of flexibility and quick adaptation to the new requirements of production and global market, exposure to new industrial know-hows $[55,56]$, the ability to identify and to apply the value of novel external information [57], the power to speedily adopt the modern techniques and technologies for new business models [58], the rapid decision and the lack of bureaucracy in the process of implementing new products and innovative processes [59]. As such, a crucial role in shaping a competitive benefit is revealed by innovation [29]. Exposito and Sanchis-Llopis [39] noticed that innovation of any type (product, process and/or organizational) positively influences financial and operational extents of SME performance. As well, The Organisation for Economic Co-operation and Development (OECD) [60] reinforced that higher levels of firms' investment in innovation determine higher innovation sales and productivity.

The competitiveness regarding a company refers to "the capacity of producing proper goods and services of eligible quality, at the right price and at the right time" [61] or "the capacity of companies to compete, to develop and to increase profits" [62]. Also, competitiveness is viewed as the "dynamic function that depends on progress, innovation and on the ability to self-change and improve" [23]. Through his pattern, Porter [23] reinforces the idea that, even if the production of globalization takes place along with the commercial changes, the competitive advantage is created and supported through a local process. The national or regional area is the one which, through its economic, cultural or institutional propriety, allows the development of certain economic activities, of specific undergrowth or branches of activity or not.

Along with the industrial development and the improvement in the knowledge society, the usage of knowledge had become the new economic important resource, which changes the approach towards performance and competitiveness completely. The company's resources support its competitive advantage [63], and the manager must nowadays analyze the production along with its social concerns, labor conditions and the value of the local consumption [64]. A new capability of the entrepreneur regarding the business success is emphasized, regarding the social competence [65], and the communication manner with the providers and the clients, the promoting strategy and the usage of proper visual symbols [66].

The practice strategy has proven that within one company competitiveness often requires a long learning process which, at the local level can be attained through a common effort of all the universities, research institutions, investors and entrepreneurs by creating and developing certain powerful networks [67] with the purpose of reinforcing some new technologies and by creating some business incubators [68] that might support the local innovation process. However, competitiveness will be emphasized not only by quality and performance, but also by the plentiful processes within the company. Amongst these types of processes, the managerial ones are really imperative. Thus, there are studies [69] that show that the management of SMEs, having solid positions on the market, usually make more conservative choices of disengagement resources, in order to preserve and strengthen the actual profit. The experience accumulated on the market and the market feedback is required to build a strategy appropriate to local conditions.

Innovation represents the process of placing a certain product on the market (goods or services), a new one or a significantly improved one. Innovation focuses on the cooperation between research and industry, due to the need for finalizing the research through practical results related to the technical and technological developments. In Romania, innovation is defined [70] as being both a process and a product: "innovation—as a product—represents a new function, or the improvement or a broader function of a certain product, process or service, in any domain, which can or could be available to the demand on the market, 
which may or might generate a new type of market; innovation - as a process-represents the activity that allows the occurrence of innovation. Innovation-as a process - includes the connection between research and development". To all the above mentioned, typically, the marketing innovation and the organizational innovation can be added, offering extremely more development opportunities, that allow the usage of high technologies and modern informational technologies for structure and management. Likewise, OECD [71] defines four types of innovation, namely "product innovation—the introduction of a good or service that is new or significantly improved with respect to its characteristics or intended uses; process innovation - the implementation of a new or significantly improved production or delivery method; marketing innovation - the implementation of a new marketing method involving significant changes in product design or packaging, product placement, product promotion or pricing; organizational innovation - the implementation of a new organizational method in the firm's business practices, workplace organization or external relations". Saridakis, et al. [72] differentiate amid radical innovation defined as progression in knowledge due to the advance of novel products and processes that are new to the market/industry and incremental innovation defined as an unremitting enhancement to products, processes or services that are novel to the firm only.

The practice has shown that the innovation process of a certain product, service or new performant technology is inseparably connected to intense research-development activity within companies, among universities, research institutions and other research entities, experts or scientists within all domains. By usually working on partnerships for different well-defined projects, implemented and monitored, these communities include the best professionals in the domain, human resources with high qualifications and outcomes in the fields, integrated into real scientific communities and able to reach the best performance. Globalization, the virtual, extremely dynamic market, the technological development, the computerization and the quick digitization determine the involvement of these communities even more within economy, social and cultural life at the national and regional level. This is the only way to withdraw the major differences between nations and regions and amid companies. As such, the EU determines the general policy, accepted by all the participating countries, of allocating the amount of 3\% of GDP for the activities performed in the research and development field. The national budgets allocated to research are distributed on research subjects with well-defined results which are monitored along the entire process. Among all these, the most important ones are the entrepreneurial and management culture, their capacities of identifying innovation opportunities [73], to work on a project basis and to identify, diminish or remove the potential risks of the projects [74].

The research and innovation activities include, as a direct result, the increase of jobs, an economic increase and an increase in the quality of life. The new technologies support the new approach to social problems such as poverty, poor health and environmental degradation or work safety, since SMEs are supported by a series of national or regional regulations [75], specially designed as political and social risk management strategies.

Consequently, the second set of hypotheses are explored:

Hypothesis 2a. The turnover of all active enterprises at the national level is determined by the expenditures on innovation performed by SMEs and big enterprises.

Hypothesis $\mathbf{2} \mathbf{b}$. The turnover of all active enterprises at the national level is driven by expenditures on innovation performed by all enterprises.

Hypothesis 2c. The turnover of all active enterprises at the national level is determined by the expenditures on innovation performed by all SMEs. 


\section{Data and Methodology}

\subsection{Sample Description and Variables}

The research sample consisted of business statistics-series-business-demography, over the period 2009-2017, the data source shown by the Romanian Statistical Yearbook. The selected variables are presented in Table 1.

Table 1. Variables' description.

\begin{tabular}{|c|c|}
\hline Variables & Definitions \\
\hline \multicolumn{2}{|r|}{ Variables regarding business turnover (Dependent Variables) } \\
\hline TY1A & The turnover of all active enterprises at the national level \\
\hline $\mathrm{Y} 1 \mathrm{~B}$ & The turnover of all the micro-enterprises at the national level \\
\hline \multicolumn{2}{|r|}{ Variables regarding investments (Explanatory Variables) } \\
\hline TX1A1 & Total gross investments obtained by all active enterprises at the national level \\
\hline TX1B1 & Total gross investments performed by the micro companies \\
\hline TX1C1 & Total gross investments performed by the small companies \\
\hline TX1D1 & Total gross investments performed by the middle-sized companies \\
\hline TX1E1 & Total gross investments performed by the big companies \\
\hline X1B2 & Net investments performed by micro-enterprises \\
\hline \multicolumn{2}{|r|}{ Variables regarding expenditures on innovation (Explanatory Variables) } \\
\hline TX4A & Expenditures on innovation performed by all enterprises \\
\hline TX4D & Expenditures on innovation performed by SMEs \\
\hline TX4E & Expenditures on innovation performed by big enterprises \\
\hline \multicolumn{2}{|r|}{ Variables regarding firm size (Explanatory Variables) } \\
\hline TX3A & The number of employees out of all active enterprises at the national level \\
\hline $\mathrm{X} 3 \mathrm{~B}$ & The number of employees out of active micro-units \\
\hline \multicolumn{2}{|r|}{ Variables regarding the number of enterprises } \\
\hline $\mathrm{X} 2 \mathrm{~B}$ & The number of active micro-units \\
\hline
\end{tabular}

Consistent with prior studies $[2,6,20,32,39,42,48,72]$, turnover was selected in order to catch the territorial economic growth, alongside investments [32], firm size [6,28,48,52,72], expenditures on innovation $[47,72]$ and the number of enterprises.

\subsection{Econometric Framework}

With the purpose to examine the expressed hypotheses, similar to previous studies [2,32,53], we estimate ordinary least squares (OLS) regressions. The log-log form is adopted, with MacKinnonWhite (HC2) heteroskedasticity-consistent standard errors and covariance. In order to ensure the same order of magnitude, the logarithmic transformation was achieved for all the selected variables, except the net investments performed by micro-enterprises at the national level (X1B2) due to several zero values. There will be estimated regression equations for each of the settled hypotheses, as depicted below.

Model 1 (M1). TY1A is the selected dependent variable that signifies the turnover of all active enterprises at the national level. The independent variables are TX1A1 representing the total gross investments acquired by these companies, alongside TX3A signifying the number of employees. A model of linear regression is built with two independent variables, $\beta_{1}, \beta_{2}$ and $\beta_{3}$ representing the 
parameters of the regression model and $\varepsilon_{\mathrm{i}}$ the disturbance term. The equation of the multiple linear regression is depicted below:

$$
\log (\mathrm{TY} 1 \mathrm{~A})=\beta_{1}+\beta_{2}{ }^{*} \log (\mathrm{TX} 1 \mathrm{~A} 1)+\beta_{3}{ }^{*} \log (\mathrm{TX} 3 \mathrm{~A})+\varepsilon_{\mathrm{i}}
$$

Model 2 (M2). TY1A is the chosen predicted variable that depicts the turnover of all the companies at the national level. The explanatory variable is TX1A1 representing the total gross investments performed by these companies. A set of data with 64 values from eight regions of development for a period of eight years (2009-2016) is considered. A model of linear regression with a single independent variable is built, where $\beta_{1}$ and $\beta_{2}$ are the parameters of the regression model and $\varepsilon_{i}$ the error term. The equation of the model of the univariate linear regression is described beneath:

$$
\log (\mathrm{TY} 1 \mathrm{~A})=\mathrm{C}(1)+\beta_{2}{ }^{*} \log (\mathrm{TX} 1 \mathrm{~A} 1)+\varepsilon_{\mathrm{i}} .
$$

Model 3 (M3). TY1A is the elected explained variable that shows the turnover of all the companies at the national level. The predictor variables are TX1B1, TX1C1, TX1D1 and TX1E1 showing the total gross investments performed by the micro, small, middle-sized and big companies. A model of linear regression with four independent variables is estimated, $\beta_{1}, \beta_{2}, \beta_{3}, \beta_{4}$ and $\beta_{5}$ being the parameters of the regression model and $\varepsilon_{\mathrm{i}}$ the error term. The equation of the model of multiple linear regression is shown underneath:

$$
\log (\mathrm{TY} 1 \mathrm{~A})=\beta_{1}+\beta_{2}{ }^{*} \log (\mathrm{TX} 1 \mathrm{~B} 1)+\beta_{3}{ }^{*} \log (\mathrm{TX} 1 \mathrm{C} 1)+\beta_{4}{ }^{*} \log (\mathrm{TX} 1 \mathrm{D} 1)+\beta_{5}{ }^{*} \log (\mathrm{TX} 1 \mathrm{E} 1)+\varepsilon_{\mathrm{i}}
$$

Model 4 (M4). Y1B is the selected dependent variable that represents the turnover of all the micro-enterprises at the national level. The regressors are X1B2 depicting the net investments performed by these companies, $\mathrm{X} 2 \mathrm{~B}$ representing the number of active micro-units and $\mathrm{X} 3 \mathrm{~B}$ measuring the number of employees. The data series includes 832 values, corresponding to the eight regions of development, regarding 8 years and 13 sectors of the economy. A model of linear regression is estimated, having three independent variables, where $\beta_{1}, \beta_{2}, \beta_{3}$ and $\beta_{4}$ depict the parameters of the regression model and $\varepsilon_{\mathrm{i}}$ the disturbance term. The equation of the multiple linear regression model is described below:

$$
\log (\mathrm{Y} 1 \mathrm{~B})=\beta_{1}+\beta_{2}{ }^{*} \log (\mathrm{X} 1 \mathrm{~B} 2)+\beta_{3}{ }^{*} \log (\mathrm{X} 2 \mathrm{~B})+\beta_{4}{ }^{*} \log (\mathrm{X} 3 \mathrm{~B})+\varepsilon_{\mathrm{i}}
$$

Model 5 (M5). It is considered that the turnover at the national level is determined by the expenditures on innovation performed by companies. It is analyzed based on two size categories: SMEs and big enterprises. TY1A is the chosen regress and that represents the turnover of all the companies at the national level. The independent variables are TX4D and TX4E that catches the expenditures on innovation performed by SMEs and big enterprises. The data series includes 24 values, corresponding to the eight development regions for three years. However, in the Romanian Statistical Yearbook, the data regarding expenditures on innovation are reported every two years. A model of linear regression with two independent variables is estimated, $\beta_{1}, \beta_{2}$ and $\beta_{3}$ showing the parameters of the regression model and $\varepsilon_{\mathrm{i}}$ the disturbance term. The equation of the model of multiple linear regression is represented below:

$$
\log (\mathrm{TY} 1 \mathrm{~A})=\beta_{1}+\beta_{2}{ }^{*} \log (\mathrm{TX} 4 \mathrm{E})+\beta_{3}{ }^{*} \log (\mathrm{TX} 4 \mathrm{D})+\varepsilon_{\mathrm{i}}
$$

Model 6 (M6). It is considered that the turnover at the national level is driven by the total expenditures achieved by enterprises. TY1A is established as the dependent variable that signifies the turnover of all the companies at the national level. The independent variable is represented by TX4A that measures the expenditures on innovation performed by all companies. A model of linear regression with a single independent variable is estimated, where $\beta_{1}$ and $\beta_{2}$ are the parameters of 
the regression model and $\varepsilon_{\mathrm{i}}$ the error term. The equation of the model of simple linear regression is depicted underneath:

$$
\log (\mathrm{TY} 1 \mathrm{~A})=\beta_{1}+\beta_{2}{ }^{*} \log (\mathrm{TX} 4 \mathrm{~A})+\varepsilon_{\mathrm{i}}
$$

Model 7 (M7). It is considered that the turnover at the national level is determined by the expenditures on innovation performed by companies. TY1A is acknowledged as the response variable that catches the turnover of all the companies at the national level. The explanatory variable is TX4E that measures the expenditures on innovation performed by all SMEs. A model of simple linear regression with a single independent variable is estimated, where $\beta_{1}$ and $\beta_{2}$ are the parameters of the regression model and $\varepsilon_{\mathrm{i}}$ the disturbance term. The equation of the model of simple linear regression is defined underneath:

$$
\log (\mathrm{TY} 1 \mathrm{~A})=\beta_{1}+\beta_{2}{ }^{*} \log (\mathrm{TX} 4 \mathrm{E})+\varepsilon_{\mathrm{i}}
$$

\section{Empirical Findings and Discussion}

\subsection{Preliminary Analysis}

The data regarding the total turnover of Romanian enterprises is analyzed further. Table 2 concerns the local active units from industry, construction, trade and other services from the eight Romanian development regions.

Table 2. Total turnover for the active local units from industry, construction, trade and other services.

\begin{tabular}{ccccccccc}
\hline Region & $\mathbf{2 0 0 9}$ & $\mathbf{2 0 1 0}$ & $\mathbf{2 0 1 1}$ & $\mathbf{2 0 1 2}$ & $\mathbf{2 0 1 3}$ & $\mathbf{2 0 1 4}$ & $\mathbf{2 0 1 5}$ & $\mathbf{2 0 1 6}$ \\
\hline 1 North-West & 85,673 & 91,222 & 101,068 & 106,958 & 10,8911 & 115,831 & 124,021 & 134,251 \\
\hline 2 Center & 88,253 & 95,354 & 106,679 & 114,973 & 119,574 & 126,904 & 133,324 & 143,313 \\
\hline 3 North-East & 60,414 & 61,355 & 67,979 & 75,897 & 75,251 & 77,896 & 84,512 & 89,131 \\
\hline 4 South-East & 86,943 & 93,476 & 103,380 & 115,446 & 106,792 & 106,701 & 110,370 & 106,377 \\
\hline 5 South-Muntenia & 97,848 & 107,136 & 128,467 & 132,425 & 130,652 & 137,503 & 138,421 & 145,959 \\
\hline 6 Bucharest-Ilfov & 316,201 & 332,956 & 360,042 & 363,868 & 363,665 & 381,902 & 415,115 & 430,203 \\
\hline 7 South-West Oltenia & 49,527 & 50,953 & 57,426 & 61,734 & 59,110 & 61,177 & 64,697 & 66,159 \\
\hline 8 West & 65,975 & 70,786 & 82,110 & 89,207 & 91,037 & 97,804 & 106,706 & 117,095 \\
\hline
\end{tabular}

Source: Authors' processing from the Romanian Annual Statistical Yearbook 2010-2017 National Institute of Statistics [76].

In line with Table 2 and Figure 1, we notice that for region number six, Bucharest-Ilfov, the one that includes the capital and the neighboring areas, there is a superior development level compared to other areas. This may occur probably due to the more attractive business environment, offering both opportunities for new companies and qualified, trained personnel with great experience in management, better access to various resources, infrastructure, specialists and links with academics.

The annual turnover for big, active companies at the national level, and the ones accomplished by SMEs, is reported in Table 3, whereas Figure 2 reveals that the SMEs' total turnover exceeds the turnover of big enterprises. 


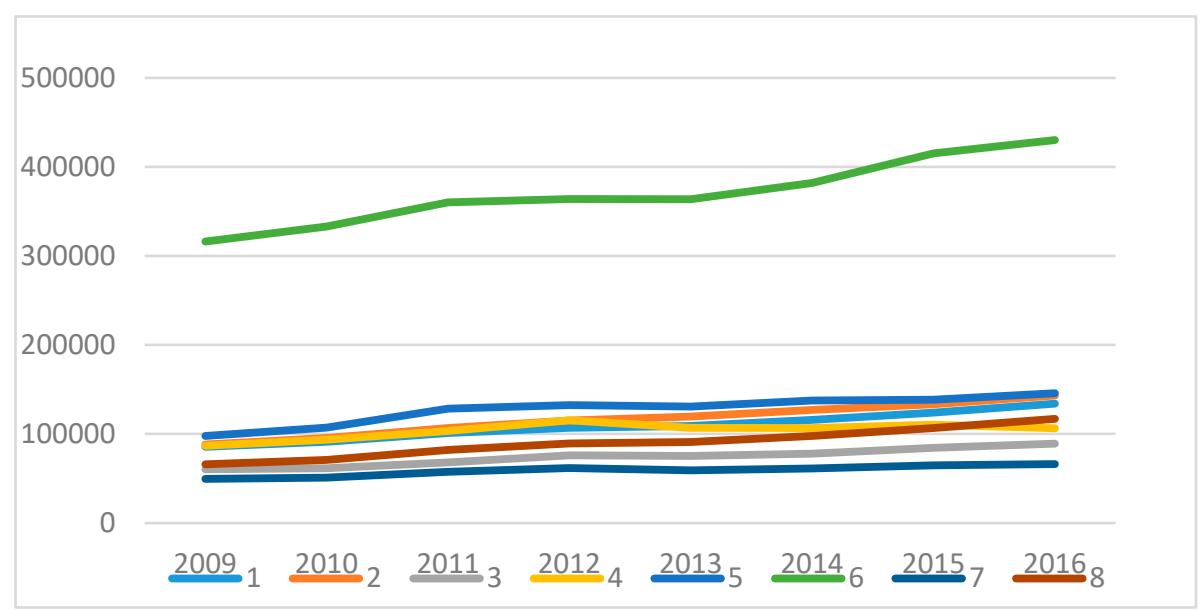

Figure 1. The total turnover of the first companies from the eight developed regions. Source: Authors' processing from the Romanian Annual Statistical Yearbook 2010-2017 [76].

Table 3. The turnover of active companies, small and medium enterprises (SMEs) and big enterprises (mil Lei).

\begin{tabular}{ccccc}
\hline Year/No. of Employees & $\mathbf{0 - 9}$ & $\mathbf{1 0 - 4 9}$ & $\mathbf{5 0 - 2 4 9}$ & $\mathbf{2 5 0}$ \\
\hline 2009 & 172,783 & 209,784 & 226,239 & 242,028 \\
\hline 2010 & 178,450 & 221,111 & 236,806 & 266,871 \\
\hline 2011 & 193,513 & 241,214 & 264,461 & 307,963 \\
\hline 2012 & 212,861 & 264,998 & 267,928 & 314,721 \\
\hline 2013 & 200,138 & 258,106 & 282,285 & 314,464 \\
\hline 2014 & 212,025 & 276,365 & 287,391 & 329,936 \\
\hline 2015 & 217,517 & 295,635 & 314,397 & 349,618 \\
\hline 2016 & 220,570 & 303,257 & 337,667 & 370,994 \\
\hline
\end{tabular}

Source: Authors' processing from the Romanian Statistical Yearbook 2010-2017 [76].

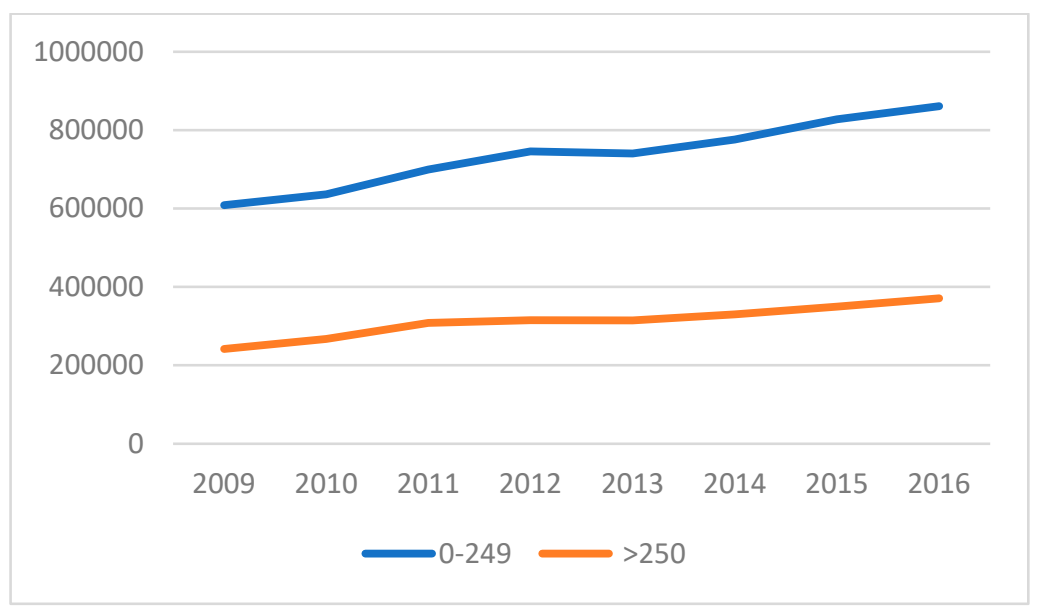

Figure 2. The turnover of SMEs (0-249 employees) and of big enterprises. Source: Authors' processing from the Romanian Annual Statistical Yearbook 2010-2017 [76].

Thus, it is proven that there is a greater importance that needs to be granted to the support and development of SMEs, as a pillar of the territorial development, through the governmental, European or regional policies belonging to the local and central administrative policymakers. 
By analyzing the turnover of enterprises of different sizes, as conveyed in Table 4, even if all of them experienced the same upward trajectory, Figure 3 reveals that the big enterprises have a greater value for this indicator. Nevertheless, all of these cumulated data indicate that SMEs may greatly exceed this value (Figure 2).

Table 4. The turnover of active companies and the size categories (mil Lei).

\begin{tabular}{ccc}
\hline Year & SMEs (0-249) & Big Companies $(>\mathbf{2 5 0 )}$ \\
\hline 2009 & 608,806 & 242,028 \\
\hline 2010 & 636,367 & 266,871 \\
\hline 2011 & 699,188 & 307,963 \\
\hline 2012 & 745,787 & 314,721 \\
\hline 2013 & 740,529 & 314,464 \\
\hline 2014 & 775,781 & 329,936 \\
\hline 2015 & 827,549 & 349,618 \\
\hline 2016 & 861,494 & 370,994 \\
\hline
\end{tabular}

Source: Authors' processing from the Romanian Statistical Yearbook 2010-2017 [76].

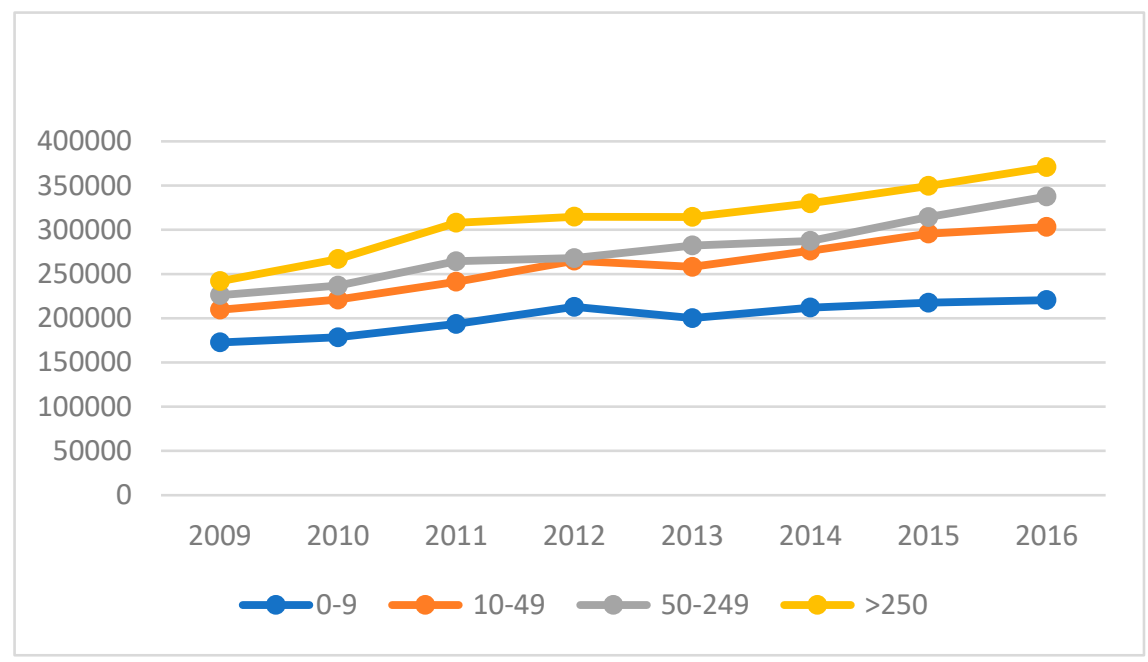

Figure 3. Turnover of enterprises regarding the size category. Source: Authors' processing from the Romanian Annual Statistical Yearbook 2010-2017 [76].

By exploring the expenditures on innovation performed by SMEs and big enterprises in Romania, as showed in Table 5 and Figure 4, it is noted that, at the national level, the innovation spending related to SMEs follows the increased tendency of big enterprises, even the absolute value is smaller than the one of the big companies. A closer analysis of years and regions of development, reported in Table 6 and Figure 5, shows that in Romania, the total innovation of SMEs from the Bucharest-Ilfov region is larger than the innovation registered in the other regions. Thus, it is confirmed that an attractive region, such as the capital city of a country, offers suitable transport infrastructure, business opportunities, experience and better collaboration with the academic and research community, human resources of various specializations and a competitive and challenging environment. The innovation of SMEs depends to a large extent on the specificity of the company [77], in close relation to the company's position on the market and its connection to the market's request. It also hinges on its organizational strategy and its management, on the protection offered for different measures of prevention and protection against the risks that may occur especially in the field of investment. 
Table 5. Expenditures on innovation of SMEs and big enterprises (mil Lei).

\begin{tabular}{ccc}
\hline Year & Big & SMEs \\
\hline 2012 & $1,663,447$ & $1,253,844$ \\
\hline 2014 & $2,068,974$ & $1,369,763$ \\
\hline 2016 & $3,732,421$ & $2,623,607$
\end{tabular}

Source: Authors' processing from the Romanian Statistical Yearbook 2010-2017 [76].

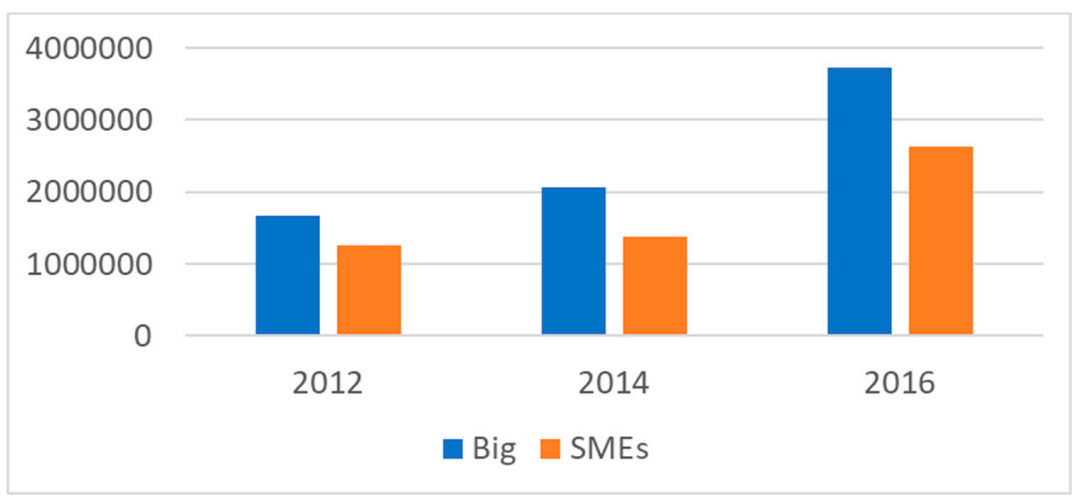

Figure 4. The value of expenditures on the innovation of SMEs and big enterprises. Source: Authors' processing from the Romanian Annual Statistical Yearbook 2010-2017 [76].

Table 6. Expenditures on innovation within active enterprises depending on regions (mil Lei).

\begin{tabular}{cccc}
\hline Region & $\mathbf{2 0 1 2}$ & $\mathbf{2 0 1 4}$ & $\mathbf{2 0 1 6}$ \\
\hline 1 North-West & 251,952 & 111,085 & 82,354 \\
\hline 2 Center & 401,308 & 353,020 & 496,385 \\
\hline 3 North-East & 188,403 & 287,744 & 66,920 \\
\hline 4 South-East & 686,340 & 490,651 & 284,162 \\
\hline 5 South-Muntenia & 277,680 & 628,358 & 283,633 \\
\hline 6 Bucharest-Ilfov & 861,600 & $1,145,411$ & 537,984 \\
\hline 7 South-West Oltenia & 123,233 & 15,789 & 4912 \\
\hline 8 West & 126,775 & 406,679 & 57,815
\end{tabular}

Source: Authors' processing from the Romanian Statistical Yearbook 2010-2017 [76].

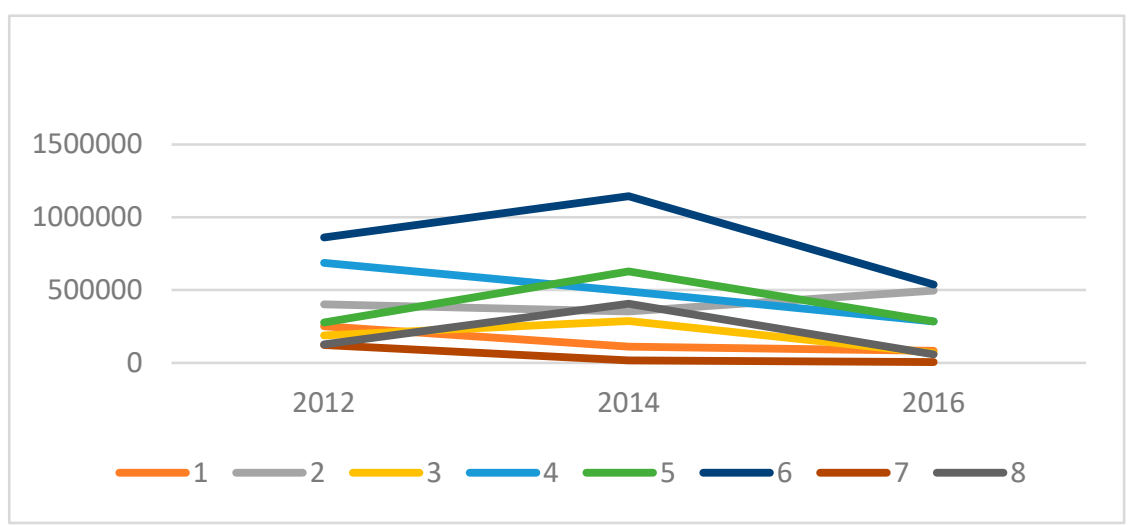

Figure 5. Total expenditures on innovation for the enterprises in the eight regions of development. Source: Authors' processing from the Romanian Annual Statistical Yearbook 2010-2017 [76]. 
Prior studies show that most of these problems may be recognized and solved through an extensive-learning organizational process. Its features are the capacity to successfully influence the organizational performance of SMEs [78,79], the ability to lead on a competitive advantage [80] to a strong performance of the business model [81] mirrored through the turnover, as well as to foster social responsibility measures along with development and competitive growth [82]. The organizational capacity of learning may manifest itself via certain actual mechanisms, such as experimentation, risk-taking, interaction with the external environment, the dialogue and the participatory decision-making process [83]. It can also manifest itself through adopting modern high-performance technologies [84] proving the importance of learning over the study of the market [85] and of the clients' choices on a very dynamic actual market [86]. These all contribute to the valuable effect on the performance of SMEs regarding the ecological dynamism [87], of green products [88] and of the investments regarding the training and specialization of the human resource [89].

SMEs' development and their orientation in an extremely dynamic global market are reliant on the educational and continuous training process of human resources for new specializations, that may ensure the usage of new high-performance technologies in conditions of high performance for enterprises [90]. The two conditions are essentially related as follows: the human resources training limits the usage of new technologies in the field for active companies and even for their management [91]. In response, all these will create certain conditions regarding the performed investments and innovations of the management teams in general, and of the SMEs in particular. The SMEs with a lower rate of bureaucracy, with a greater flexibility and a more rapid capability to adapt to the market requests, may grow, may develop more efficiently through investments and innovation expenditures, in all its forms.

\subsection{Regression Models Outcomes}

\subsubsection{The Impact of Investments on Territorial Economic Growth}

The empirical outcomes of the first regression model are reported in Table 7. The estimated value of the coefficient of determination (R-squared) reveals that the variation of the values of the independent variables (TX1A1 and TX3A) explains the variation of the dependent variable (TY1A) on a ratio of $90.59 \%$. For each $1 \%$ increase in the value of gross investments (TX1A1), turnover (TY1A) increases by $0.25 \%$. Therefore, the neoclassical theory [51] is supported. Also, if the number of employees (TX3A) increases by one percent, turnover will increase by $1.11 \%$, as in prior studies [6,28]. Hence, Hypothesis $1 \mathrm{a}$ is confirmed, the turnover at the national level being determined by the investments performed by companies and by the number of employees.

With reference to the second hypothesis, the empirical estimations are shown in Table 8. The estimated value of the R-squared reveals the fact that the variation of the values of the independent variable (TX1A1) explains the variation of the dependent variable to an extent of $79.69 \%$. If the value of gross investments (TX1A1) rises by one percent, turnover will increase by $0.77 \%$. Consistent with the results from Table 7 , the investments will determine an intensification of the profitability, consistent with [49]. Thereby, Hypothesis $1 \mathrm{~b}$ is confirmed, the turnover at the national level being determined by the investments performed by companies. 
Table 7. Estimated parameters of the multiple linear regression model M1 by using the method of least squares.

\begin{tabular}{ccccc}
\hline Variable & Coefficient & Std. Error & t-Statistic & Prob. \\
\hline C & -5.198040 & 1.723701 & -3.015628 & 0.0037 \\
\hline $\log ($ TX1A1) & 0.254622 & 0.135583 & 1.877976 & 0.0652 \\
\hline $\log (\mathrm{TX} 3 \mathrm{~A})$ & 1.105328 & 0.225105 & 4.910274 & 0.0000 \\
\hline R-squared & 0.905874 & Mean dependent var & 11.61481 \\
\hline Adjusted R-squared & 0.902788 & S.D. dependent var & 0.532504 \\
\hline S.E. of regression & 0.166028 & Akaike info criterion & -0.707575 \\
\hline Sum squared resid & 1.681492 & Schwarz criterion & -0.606377 \\
\hline Log likelihood & 25.64239 & Hannan-Quinn criter. & -0.667708 \\
\hline F-statistic & 293.5348 & Durbin-Watson stat & 1.015572 \\
\hline Prob(F-statistic) & 0.000000 & Wald F-statistic & 648.6972 \\
\hline Prob(Wald F-statistic) & 0.000000 & &
\end{tabular}

Source: Authors' estimations. Notes: dependent variable: $\log (\mathrm{TY} 1 \mathrm{~A})$. Method: least squares. MacKinnon-White (HC2) heteroskedasticity-consistent standard errors and covariance. Sample: 1 64. Included observations: 64.

Table 8. Estimated parameters of the simple linear regression model M2 by using the method of least squares.

\begin{tabular}{ccccc}
\hline Variable & Coefficient & Std. Error & $t$-Statistic & Prob. \\
\hline C & 4.452171 & 0.683106 & 6.517543 & 0.0000 \\
\hline $\log ($ TX1A1) & 0.768108 & 0.074703 & 10.28216 & 0.0000 \\
\hline R-squared & 0.796887 & Mean dependent var & 11.61481 \\
\hline Adjusted R-squared & 0.793611 & S.D. dependent var & 0.532504 \\
\hline S.E. of regression & 0.241917 & Akaike info criterion & 0.030305 \\
\hline Sum squared resid & 3.628470 & Schwarz criterion & 0.097770 \\
\hline Log likelihood & 1.030236 & Hannan-Quinn criter. & 0.056883 \\
\hline F-statistic & 243.2494 & Durbin-Watson stat & 1.441618 \\
\hline Prob(F-statistic) & 0.000000 & Wald F-statistic & 105.7228 \\
\hline Prob(Wald F-statistic) & 0.000000 & &
\end{tabular}

Source: Authors' estimations. Notes: dependent variable: $\log (\mathrm{TY} 1 \mathrm{~A})$. Method: least squares. MacKinnon-White (HC2) heteroskedasticity-consistent standard errors and covariance. Sample: 1 64. Included observations: 64.

Further, the research aims to investigate to what extent the turnover of all the companies at the national level is driven by the investments performed by companies, depending on their size (micro, small, medium and big). As regards the third model, the quantitative results are displayed in Table 9. 
Table 9. Estimated parameters of the multiple linear regression model M3 by using the method of least squares.

\begin{tabular}{ccccc}
\hline Variable & Coefficient & Std. Error & t-Statistic & Prob. \\
\hline C & 5.173465 & 0.240976 & 21.46883 & 0.0000 \\
\hline $\log (\mathrm{TX} 1 \mathrm{~B} 1)$ & 0.211263 & 0.052112 & 4.054010 & 0.0001 \\
\hline $\log (\mathrm{TX} 1 \mathrm{C} 1)$ & 0.372942 & 0.084366 & 4.420517 & 0.0000 \\
\hline $\log (\mathrm{TX} 1 \mathrm{D} 1)$ & 0.143356 & 0.084269 & 1.701164 & 0.0942 \\
\hline $\log (\mathrm{TX} 1 \mathrm{E} 1)$ & 0.109920 & 0.051485 & 2.134995 & 0.0369 \\
\hline R-squared & 0.929221 & Mean dependent var & 11.61481 \\
\hline Adjusted R-squared & 0.924422 & S.D. dependent var & 0.532504 \\
\hline S.E. of regression & 0.146393 & Akaike info criterion & -0.930141 \\
\hline Sum squared resid & 1.264421 & Schwarz criterion & -0.761479 \\
\hline Log likelihood & 34.76452 & Hannan-Quinn criter. & -0.863697 \\
\hline F-statistic & 193.6448 & Durbin-Watson stat & 1.378223 \\
\hline Prob(F-statistic) & 0.000000 & Wald F-statistic & 433.4057 \\
\hline Prob(Wald F-statistic) & 0.000000 & &
\end{tabular}

Source: Authors' estimations. Notes: dependent variable: $\log (\mathrm{TY} 1 \mathrm{~A})$. Method: least squares. MacKinnon-White (HC2) heteroskedasticity-consistent standard errors and covariance. Sample: 1 64. Included observations: 64.

The estimated value of the R-squared reveals the fact that the simultaneous variation of the values of the independent variables (TX1B1, TX1C1, TX1D1 and TX1E1) explains the variation of the dependent variable (TY1A) to an extent of $92.92 \%$. If the value of investments performed by micro-enterprises (TX1B1), small companies (TX1C1), middle-sized companies (TX1D1) or big companies (TX1E1) increases by one percent, turnover will increase by $0.21 \%, 0.37 \%, 0.14 \%$ or $0.11 \%$. Hence, Hypothesis $1 \mathrm{c}$ is confirmed, the turnover being determined by the investments performed by companies for all types of sizes. The prominence of the SMEs over the development and support of the economic growth of a certain country is proved. This reputation is acknowledged by EU legislation and regulations, through the government policies that promote the establishing, increase and financing process of SMEs. The consideration of political factors must be drawn so as to ensure easy access of these enterprises to financing resources [17], alongside better and various development opportunities. Also, SMEs that are flexible due to their size, organization and dynamics are easily adaptable to the market request. They must wisely arrange their investments to a high implementation level of the technology and to the automation process of all the activities, to ensure work and environment conditions according to modern standards, besides the products and processes innovation. All these are attracted and implemented by a modern management that uses techniques, procedures and up-to-date programming and control instruments which would ensure the existence and the development of the long-term of the SMEs, in the context of a continuously fluctuating market.

The estimations related to the fourth econometric model are conveyed in Table 10. The estimated value of the R-squared reveals the fact that the variation of the values of the independent variables (X1B2, X2B and X3B) explains the variation of the dependent variable (Y1B) to an extent of $75.92 \%$. 
Table 10. Estimated parameters of the multiple linear regression model M4 by using the method of least squares.

\begin{tabular}{ccccc}
\hline Variable & Coefficient & Std. Error & t-Statistic & Prob. \\
\hline C & -0.572733 & 0.199315 & -2.873508 & 0.0042 \\
\hline X1B2 & 0.000609 & 0.000151 & 4.020901 & 0.0001 \\
\hline $\log ($ X2B $)$ & 0.350974 & 0.047841 & 7.336311 & 0.0000 \\
\hline $\log ($ X3B $)$ & 0.507031 & 0.050006 & 10.13947 & 0.0000 \\
\hline R-squared & 0.759192 & Mean dependent var & 6.146454 \\
\hline Adjusted R-squared & 0.758319 & S.D. dependent var & 1.689388 \\
\hline S.E. of regression & 0.830521 & Akaike info criterion & 2.471268 \\
\hline Sum squared resid & 571.1249 & Schwarz criterion & 2.493979 \\
\hline Log likelihood & -1024.047 & Hannan-Quinn criter. & 2.479976 \\
\hline F-statistic & 870.1407 & Durbin-Watson stat & 0.371520 \\
\hline Prob(F-statistic) & 0.000000 & Wald F-statistic & 538.1923 \\
\hline Prob(Wald F-statistic) & 0.000000 & &
\end{tabular}

Source: Authors' estimations. Notes: dependent variable: $\log (\mathrm{Y} 1 \mathrm{~B})$. Method: least squares. MacKinnon-White (HC2) heteroskedasticity-consistent standard errors and covariance. Sample: 1 832. Included observations: 832.

For each $1 \%$ increase in the number of micro-units $(\mathrm{X} 2 \mathrm{~B})$ and the number of employees in a micro-enterprise (X3B), turnover (TY1A) increases by $0.35 \%$ and $0.51 \%$, respectively. A one-unit increase in net investments performed by micro-enterprises (X1B2) will generate an increase in the geometric mean of turnover by $0.06 \%$. Nevertheless, for small firms, the sales revenues are regularly more appropriate in overcoming liquidity problems than for funding the investment [42]. As such, Hypothesis $1 \mathrm{~d}$ is confirmed, the turnover of micro-enterprises at the national level being determined by the investments performed by companies, by the number of micro active units and by the number of the employees. Nevertheless, with reference to this category of enterprises, the investments are even more difficult to be implemented because the company should access external financing resources.

\subsubsection{The Impact of Innovation on Territorial Economic Growth}

The outcomes of the fifth regression model are exhibited in Table 11. The estimated value of the $\mathrm{R}$-squared reveals the fact that the simultaneous variation of the values of the independent variables (TX4E and TX4D) explains, to an extent of 59.21\%, the variation of the dependent variable (TY1A). For each $1 \%$ increase in the value of expenditures on innovation performed by big companies (TX4E), turnover (TY1A) increases by $0.37 \%$. Besides, in the case of SMEs, the relationship between expenditures on innovation and turnover is not statistically significant. Unfortunately, in line with Armeanu, Istudor and Lache [38], Romanian SMEs reveal a reduced ability to innovate, alongside their concentration in low-value-added generating areas, restricted access to financing and poor management. Therefore, Hypothesis 2a is confirmed only for SMEs. 
Table 11. Estimated parameters of the multiple linear regression model M5 by using the method of least squares.

\begin{tabular}{ccccc}
\hline Variable & Coefficient & Std. Error & $t$-Statistic & Prob. \\
\hline C & 8.513681 & 0.645311 & 13.19313 & 0.0000 \\
\hline $\log ($ TX4D) & -0.078573 & 0.075360 & -1.042647 & 0.3090 \\
\hline $\log (\mathrm{TX} 4 \mathrm{E})$ & 0.369872 & 0.092168 & 4.013022 & 0.0006 \\
\hline R-squared & 0.592076 & Mean dependent var & 11.70371 \\
\hline Adjusted R-squared & 0.553226 & S.D. dependent var & 0.520231 \\
\hline S.E. of regression & 0.347729 & Akaike info criterion & 0.841681 \\
\hline Sum squared resid & 2.539221 & Schwarz criterion & 0.988937 \\
\hline Log likelihood & -7.100167 & Hannan-Quinn criter. & 0.880748 \\
\hline F-statistic & 15.24007 & Durbin-Watson stat & 1.142976 \\
\hline Prob(F-statistic) & 0.000081 & Wald F-statistic & 13.00972 \\
\hline Prob(Wald F-statistic) & 0.000211 & & \\
\hline
\end{tabular}

Source: Authors' estimations. Notes: dependent variable: $\log ($ TY1A). Method: least squares. MacKinnon-White (HC2) heteroskedasticity-consistent standard errors and covariance. Sample: 124 . Included observations: 24.

The results regarding the examination of the sixth hypothesis are presented in Table 12 . The estimated value of the R-squared reveals the fact that the variation of the independent variable (TX4A) explains, to an extent of $39.01 \%$, the variation of the dependent variable (TY1A). Also, if the value of expenditures on innovation performed by all enterprises increases by one percent, turnover will increase by $0.26 \%$. Consistent with Exposito and Sanchis-Llopis [39], the introduction of product innovation emphasizes a positive impact on the probability of sales intensification. Hence, Hypothesis $2 \mathrm{~b}$ is confirmed.

Table 12. Estimated parameters of the simple linear regression model M6 by using the method of least squares.

\begin{tabular}{ccccc}
\hline Variable & Coefficient & Std. Error & $t$-Statistic & Prob. \\
\hline C & 8.564310 & 0.896656 & 9.551389 & 0.0000 \\
\hline $\log (\mathrm{TX} 4 \mathrm{~A})$ & 0.256394 & 0.075632 & 3.390020 & 0.0026 \\
\hline R-squared & 0.390104 & Mean dependent var & 11.70371 \\
\hline Adjusted R-squared & 0.362382 & S.D. dependent var & 0.520231 \\
\hline S.E. of regression & 0.415410 & Akaike info criterion & 1.160553 \\
\hline Sum squared resid & 3.796439 & Schwarz criterion & 1.258725 \\
\hline Log likelihood & -11.92664 & Hannan-Quinn criter. & 1.186598 \\
\hline F-statistic & 14.07174 & Durbin-Watson stat & 1.684148 \\
\hline Prob(F-statistic) & 0.001104 & Wald F-statistic & 11.49224 \\
\hline Prob(Wald F-statistic) & 0.002633 & &
\end{tabular}

Source: Authors' estimations. Notes: dependent variable: $\log (\mathrm{TY} 1 \mathrm{~A})$. Method: least squares. MacKinnon-White (HC2) heteroskedasticity-consistent standard errors and covariance. Sample: 1 24. Included observations: 24.

The outcomes of the seventh model are reported in Table 13. The estimated value of the R-squared reveals the fact that the variation of the independent variable (TX4E) explains, to an extent of $57.44 \%$, the variation of the dependent variable (TY1A). Hence, for each $1 \%$ increase in the expenditures on innovation performed by big enterprises (TX4E), turnover (TY1A) increases by $0.31 \%$. Hereby, Hypothesis $2 \mathrm{c}$ is confirmed. Companies invest in innovation aiming to gather market share, decrease 
costs and turn out to be more prolific. Since customer requests have become more specific and competition has amplified, innovation is essential [60].

Table 13. Estimated parameters of the simple linear regression model M7 by using the method of least squares.

\begin{tabular}{ccccc}
\hline Variable & Coefficient & Std. Error & $t$-Statistic & Prob. \\
\hline C & 8.292346 & 0.739660 & 11.21103 & 0.0000 \\
\hline $\log (\mathrm{TX} 4 \mathrm{E})$ & 0.306904 & 0.068674 & 4.468970 & 0.0002 \\
\hline R-squared & 0.574391 & Mean dependent var & 11.70371 \\
\hline Adjusted R-squared & 0.555045 & S.D. dependent var & 0.520231 \\
\hline S.E. of regression & 0.347020 & Akaike info criterion & 0.800788 \\
\hline Sum squared resid & 2.649306 & Schwarz criterion & 0.898959 \\
\hline Log likelihood & -7.609451 & Hannan-Quinn criter. & 0.826832 \\
\hline F-statistic & 29.69058 & Durbin-Watson stat & 1.083840 \\
\hline Prob(F-statistic) & 0.000018 & Wald F-statistic & 19.97170 \\
\hline Prob(Wald F-statistic) & 0.000192 & & \\
\hline
\end{tabular}

Source: Authors' estimations. Notes: dependent variable: $\log ($ TY1A). Method: least squares. MacKinnon-White (HC2) heteroskedasticity-consistent standard errors and covariance. Sample: 124 . Included observations: 24.

\section{Concluding Remarks and Policy Implications}

The current study explored the impact of investments and innovation on territorial economic growth, as measured by the turnover, for Romanian business statistics series over the period 2009-2017. By estimating several log-log linear regressions, the empirical findings provide support for a positive impact of investments on territorial economic growth. The relationship was proven both for all active enterprises at the national level and for micro, small, middle and big companies. In the case of innovation-oriented expenditures, our estimation results show a positive impact on turnover for all enterprises and big companies, but a lack of association was established in the case of SMEs. Besides, there was a noticeable positive impact of firm size on turnover for all active enterprises at the national level, as well as for active micro-units. Also, the results suggested a positive influence on the number of active micro-units on territorial economic growth.

In our view, this study has some noteworthy policy implications. The managers should learn from the previous experience of other companies whose success or failure had been investigated so as to recognize the factors and relations that led to factual results [92]. These companies will have to adopt several requirements such as: A willingness to give up the traditional type of management, possible, by identifying and accepting new challenges, building an organizational structure regarding the learning process and the adoption process of new technologies along with the innovation involved within all domains. All these essentially lead to management innovation, a segment that is directly related to the organizational facet of the company [93], to the usage of new managerial practices, the practice of so-called management innovators [94]. They should try to combine the ideas gained from various studies, analyze and further adapt them to the specific needs of the intended enterprises. All these together form the organizational innovation and carry an important role regarding the results of innovation [95] aiming at the process and the final products.

In Romania a series of programs of European financial support is available to be accessed, by SMEs, through certain projects regarding development, the implementation of high technologies or the mechanization of some processes, for the instruction of employees, for the protection of the environment, for the quality assurance in all domains, to provide support for the management efficiency [96]. There are also other types of projects that help the SMEs by offering financing, funding business incubators, stimulating some activities or encourage higher employment, motivating the 
purchase and the implementation concerning information and communication technologies that form the core of development. It is vital to have a bigger financial system that is able to support entrepreneurs and the different stages of the lifecycle of small firms [46]. Higher levels of economic, financial and institutional expansion are imperative in improving firm financial restrictions [48].

This study has several restrictions. Perhaps the most constraining limitation of this research is emphasized by the selected dataset, collected from the Romanian Statistical Yearbook. Owning more disaggregated data, namely firm-level data, would allow catching more characteristics such as total assets, firm age, labor productivity or internationalization. Given that the heterogeneous aspect of SMEs hinges on the size of a region's economic activity, regional effects intended for controlling for the eight regions of Romania were not considered. As well, consistent with Motta and Sharma [28], employing the number of employees as a measure towards firm size may be challenging inasmuch as the number of employees is driven by the economic size of the company, quality of the firm, selection of operational leverage and type of business. As future research avenues, the current paper should be developed by exploring the causal relationships between, investments, innovation and territorial economic growth. As well, a sectorial analysis may depict another forthcoming direction.

Author Contributions: Conceptualization, S.C.G., M.A.B., A.H. and L.N.S.; data curation, S.C.G., M.A.B., A.H. and L.N.S.; formal analysis, S.C.G., M.A.B., A.H. and L.N.S.; funding acquisition, S.C.G., M.A.B., A.H. and L.N.S.; investigation, S.C.G., M.A.B., A.H. and L.N.S.; methodology, S.C.G., M.A.B., A.H. and L.N.S.; project administration, S.C.G., M.A.B., A.H. and L.N.S.; resources, S.C.G., M.A.B., A.H. and L.N.S.; software, S.C.G., M.A.B., A.H. and L.N.S.; supervision, S.C.G., M.A.B., A.H. and L.N.S.; validation, Ș.C.G., M.A.B., A.H. and L.N.S.; visualization, S.C.G., M.A.B., A.H. and L.N.S.; writing—original draft, S.C.G., M.A.B., A.H. and L.N.S.; Writing -review and editing, S.C.G., M.A.B., A.H. and L.N.S. All authors have read and agreed to the published version of the manuscript.

Funding: This research received no external funding.

Conflicts of Interest: The authors declare no conflict of interest.

\section{References}

1. Obi, J.; Ibidunni, A.S.; Tolulope, A.; Olokundun, M.A.; Amaihian, A.B.; Borishade, T.T.; Fred, P. Contribution of small and medium enterprises to economic development: Evidence from a transiting economy. Data Brief 2018, 18, 835-839. [CrossRef]

2. Ndiaye, N.; Razak, L.A.; Nagayev, R.; Ng, A. Demystifying small and medium enterprises' (SMEs) performance in emerging and developing economies. Borsa Istanb. Rev. 2018, 18, 269-281. [CrossRef]

3. Commission, E. Entrepreneurship and Small and Medium-Sized Enterprises (SMEs). Available online: https://ec.europa.eu/growth/smes_en (accessed on 12 August 2019).

4. European Parliament. Fact Sheets on the European Union; European Parliament: Bruxelles, Belgium, 2019.

5. Perez-Gomez, P.; Arbelo-Perez, M.; Arbelo, A. Profit efficiency and its determinants in small and medium-sized enterprises in Spain. BRQ Bus. Res. Q. 2018, 21, 238-250. [CrossRef]

6. Dowling, M.; $\mathrm{O}^{\prime}$ Gorman, C.; Puncheva, P.; Vanwalleghem, D. Trust and SME attitudes towards equity financing across Europe. J. World Bus. 2019, 54. [CrossRef]

7. Commission of the European Communities. Communication from the Commission to the Council, the European Parliament, the European Economic and Social Committee and the Committee of the Regions. In COM(2008); 394 final; Commission of the European Communities: Brussels, Belgium, 2008.

8. Yoshino, N.; Taghizadeh-Hesary, F. Optimal credit guarantee ratio for small and medium-sized enterprises' financing: Evidence from Asia. Econ. Anal. Policy 2019, 62, 342-356. [CrossRef]

9. Luo, P.F.; Wang, H.M.; Yang, Z.J. Investment and financing for SMEs with a partial guarantee and jump risk. Eur. J. Oper. Res. 2016, 249, 1161-1168. [CrossRef]

10. Winfred, A., Jr. Pro-poor economic growth: Role of small and medium sized enterprises. J. Asian Econ. 2006, $17,35-40$.

11. European Commission. Communication from the Commission to the European Parliament, the Council, the European Economic and Social Committee and the Committee of the Regions; In COM(2012) 573 final; European Commission: Brussels, Belgium, 2012. 
12. European Parliament. European Parliament Resolution of 15 June 2010 on Community Innovation Policy in a Changing World (2009/2227(INI)); European Parliament: Bruxelles, Belgium, 2010.

13. European Parliament. European Parliament Resolution of 9 March 2011 on an Industrial Policy for the Globalised Era (2010/2095(INI)); In 2012/C 199 E/16; European Parliament: Bruxelles, Belgium, 2011.

14. European Parliament. European Parliament Resolution of 23 October 2012 on Small and Medium Size Enterprises (SMEs): Competitiveness and Business Opportunities (2012/2042(INI)); In 2014/C 68 E/06; European Parliament: Bruxelles, Belgium, 2012.

15. European Parliament. European Parliament Resolution of 15 January 2014 on Reindustrialising Europe to Promote Competitiveness and Sustainability (2013/2006(INI)); In 2016/C 482/13; European Parliament: Bruxelles, Belgium, 2014.

16. European Parliament. European Parliament Resolution of 5July 2017 on Building an Ambitious EU Industrial Strategy as a Strategic Priority for Growth, Employment and Innovation in Europe; In 2017/2732(RSP); European Parliament: Bruxelles, Belgium, 2017.

17. European Parliament. European Parliament Resolution of 15 September 2016 on Access to Finance for SMEs and Increasing the Diversity of SME Funding in a Capital Markets Union (2016/2032(INI)); In 2016/2032(INI); European Parliament: Bruxelles, Belgium, 2016.

18. European Commission. Communication from the Commission to the European Parliament, the Council, the European Economic and Social Committee and the Committee of the Regions; In COM(2018) 2 final; European Commission: Brussels, Belgium, 2018.

19. Directorate-General for Research and Innovation (European Commission). Mid-Term Review of the Contractual Public Private Partnerships (cPPPs) under Horizon 2020; European Commission: Brussels, Belgium, 2017.

20. Gonzalez-Loureiro, M.; Pita-Castelo, J. A model for assessing the contribution of innovative SMEs to economic growth: The intangible approach. Econ. Lett 2012, 116, 312-315. [CrossRef]

21. Popescu, N.E. Entrepreneurship and SMEs Innovation in Romania. In Proceedings of the 21st International Economic Conference of Sibiu 2014, Iecs 2014 Prospects of Economic Recovery in a Volatile International Context: Major Obstacles, Initiatives and Projects, Sibiu, Romania, 16-17 May 2014; Volume 16, pp. 512-520. [CrossRef]

22. Porter, M.E. Competitive Advantage, Agglomeration Economies, and Regional Policy. Int. Reg. Sci. Rev. 1996, 19, 85-90. [CrossRef]

23. Porter, M.E. Customers Who Viewed Competitive Advantage: Creating and Sustaining Superior Performance, 1st ed.; Free Press: New York, NY, USA, 1998.

24. European Commission. Sixth Periodic Report on the Social and Economic Situation and Development of Regions in the European Union; European Commission: Brussels, Belgium, 1999.

25. Gardiner, B. Competitiveness Indicators for Europe-Audit, Database Construction and Analysis. Reg. Stud. Assoc. Int. Conf. 2003. Available online: http://citeseerx.ist.psu.edu/viewdoc/download?doi=10.1.1.197. 8343andrep=rep1andtype $=$ pdf (accessed on 24 August 2019).

26. Camagni, R. On the concept of territorial competitiveness: Sound or misleading? Urban Stud. 2002, 39, 2395-2411. [CrossRef]

27. Myslimi, G.; Krisdela, K. Impact of SMEs in economic growth in Albania. Eur. J. Sustain. Dev. 2016, 5, 151-158. [CrossRef]

28. Motta, V.; Sharma, A. Lending technologies and access to finance for SMEs in the hospitality industry. Int. J. Hosp. Manag. 2019, in press. [CrossRef]

29. Woźniak, M.; Duda, J.; Gąsior, A.; Bernat, T. Relations of GDP growth and development of SMEs in Poland. In Proceedings of the 23rd International Conference on Knowledge-Based and Intelligent Information and Engineering Systems, Budapest, Hungary, 4-6 September 2019.

30. Hasan, I.; Jackowicz, K.; Kowalewski, O.; Kozlowski, L. Do local banking market structures matter for SME financing and performance? New evidence from an emerging economy. J. Bank Financ. 2017, 79, 142-158. [CrossRef]

31. Sipa, M.; Gorzen-Mitka, I.; Skibinski, A. Determinants of Competitiveness of Small Enterprises: Polish Perspective. In Proceedings of the 22nd International Economic Conference of Sibiu 2015, Iecs 2015 Economic Prospects in the Context of Growing Global and Regional Interdependencies, Sibiu, Romania, 15-16 May 2015; Volume 27, pp. 445-453. [CrossRef] 
32. Jackowicz, K.; Kozlowski, L. Social ties between SME managers and bank employees: Financial consequences vs. SME managers‘ perceptions. Emerg. Mark. Rev. 2019, 40. [CrossRef]

33. Oncioiu, I.; Capusneanu, S.; Turkes, M.C.; Topor, D.I.; Constantin, D.M.O.; Marin-Pantelescu, A.; Hint, M.S. The Sustainability of Romanian SMEs and Their Involvement in the Circular Economy. Sustainable (Basel) 2018, 10, 2761. [CrossRef]

34. Neagu, C. The importance and role of small and medium-sized businesses. Theor. Appl. Econ. 2016, 23, 331-338.

35. Belu, M.G.; Popa, I.; Filip, R. The Impact of Globalisation on Small and Medium Enterprises: The Romanian Experience. Rom. Econ. J. 2018, 21, 42-51.

36. Nistor, I.E.; Popescu, D.-R. Romanian SMEs Financing Options:An Empirical Analysis. Financ. Chall. Future 2013, 1, 12-21.

37. Aceleanu, M.I.; Traşcă, D.L.; Şerban, A.C. The role of small and medium enterprises in improving employment and in the post-crisis resumption of economic growth in Romania. Theor. Appl. Econ. 2014, 1, 87-102.

38. Armeanu, D.; Istudor, N.; Lache, L. The role of smes in assessing the contribution of entrepreneurship to GDP in the romanian business environment. Amfiteatru Econ. 2015, 17, 195-211.

39. Exposito, A.; Sanchis-Llopis, J.A. The relationship between types of innovation and SMEs' performance: A multi-dimensional empirical assessment. Eurasian Bus. Rev. 2019, 9, 115-135. [CrossRef]

40. Tahir, H.M.; Razak, N.A.; Rentah, F. The Contributions of Small and Medium Enterprises (SME's) on Malaysian Economic Growth: A Sectoral Analysis. In Proceedings of the 7th International Conference on Kansei Engineering and Emotion Research 2018, Kuching, Sarawak, Malaysia, 19-22 March 2018; Springer: Berlin, Germany, 2018.

41. Ghassibe, M.; Appendino, M.; Mahmoudi, S.E. SME Financial Inclusion for Sustained Growth in the Middle East and Central Asia. In IMF Working Papers; International Monetary Fund (IMF): Washington, DC, USA, 2019.

42. Mendes, S.; Serrasqueiro, Z.; Nunes, P.M. Investment determinants of young and old Portuguese SMEs: A quantile approach. BRQ Bus. Res. Q. 2014, 17, 279-291. [CrossRef]

43. Gupta, J.; Gregoriou, A. Impact of market-based finance on SMEs failure. Econ. Model. 2018, 69, 13-25. [CrossRef]

44. Trinh, L.Q.; Doan, H.T.T. Internationalization and the growth of Vietnamese micro, small, and medium sized enterprises: Evidence from panel quantile regressions. J. Asian Econ. 2018, 55, 71-83. [CrossRef]

45. Chinembiri, T. Exploring the Role of Small and Medium Enterprises in Economic Development: Some Policy Considerations for Zimbabwe; In ZEPARU Working Paper Series; (ZEPARU); Zimbabwe Economic Policy Analysis and Research Unit (ZEPARU): Harare, Zimbabwe, 2011.

46. Wellalage, N.H.; Fernandez, V. Innovation and SME finance: Evidence from developing countries. Int. Rev. Financ. Anal. 2019, 66. [CrossRef]

47. Apanasovich, N.; Heras, H.A.; Parrilli, M.D. The impact of business innovation modes on SME innovation performance in post-Soviet transition economies: The case of Belarus. Technovation 2016, 57-58, 30-40. [CrossRef]

48. Ullah, B. Financial constraints, corruption, and SME growth in transition economies. Q. Rev. Econ. Financ. 2019, in press. [CrossRef]

49. Kersten, R.; Harms, J.; Liket, K.; Maas, K. Small Firms, large Impact? A systematic review of the SME Finance Literature. World Dev. 2017, 97, 330-348. [CrossRef]

50. Chenery, H.B. Overcapacity and the Acceleration Principle. Econometrica 1952, 20, 1-28. [CrossRef]

51. Chirinko, R.S. Business Fixed Investment Spending-Modeling Strategies, Empirical Results, and Policy Implications. J. Econ. Lit. 1993, 31, 1875-1911.

52. Baker, H.K.; Kumar, S.; Rao, P. Financing preferences and practices of Indian SMEs. Glob. Financ. J. 2017, in press.

53. Asai, Y. Why do small and medium enterprises (SMEs) demand property liability insurance? J. Bank Financ. 2019, 106, 298-304. [CrossRef]

54. Wang, Y. What are the biggest obstacles to growth of SMEs in developing countries?-An empirical evidence from an enterprise survey. Borsa Istanb. Rev. 2016, 16, 167-176. [CrossRef]

55. Agostini, L.; Filippini, R. Organizational and managerial challenges in the path toward Industry 4.0. Eur. J. Innov. Manag. 2019, 22, 406-421. [CrossRef] 
56. Mlozi, S. A Post Hoc Analysis of LearningOrientation-Innovation-Performancein the Hospitality Industry. Acad. Tur. 2017, 10, 27-41.

57. Cohen, W.M.; Levinthal, D.A. Absorptive-Capacity-A New Perspective on Learning and Innovation. Adm. Sci. Q. 1990, 35, 128-152. [CrossRef]

58. Hunter, G.K.; William, D.P., Jr. Sales Technology Orientation, Information Effectiveness, and Sales Performance. J. Pers. Sell. Sales Manag. 2006, 26, 95-113. [CrossRef]

59. Damanpour, F. The dynamics of the adoption of product and process innovations in organizations. J. Manag. Stud. 2001, 38, 45-65. [CrossRef]

60. OECD. Measuring Innovation. In A New Perspective; OECD: Paris, France, 2010.

61. Cousins, J. MBA ASAP Marketing 2.0: Principles and Practice in the Digital Age Paperback; Independently Published, 2018; Available online: https://www.amazon.com/MBA-ASAP-Marketing-2-0-Principles/dp/ 1717884334 (accessed on 24 August 2019).

62. Wignaraja, G. Competitiveness Strategy in Developing Countries. A Manual for Policy Analysis, 1st ed.; Routledge: London, UK, 2003.

63. Barney, J. Firm Resources and Sustained Competitive Advantage. J. Manag. 1991, 17, 99-120. [CrossRef]

64. Bang, A.; Cleemann, C.M.; Bramming, P. How to create business value in the knowledge economy Accelerating thoughts of Peter, F. Drucker. Manag. Decis. 2010, 48, 616-627. [CrossRef]

65. Baron, R.A.; Markman, G.D. Beyond social capital: The role of entrepreneurs' social competence in their financial success. J. Bus. Ventur. 2003, 18, 41-60. [CrossRef]

66. Clarke, J. Revitalizing Entrepreneurship: How Visual Symbols are Used in Entrepreneurial Performances. J. Manag. Stud. 2011, 48, 1365-1391. [CrossRef]

67. Prokop, D.; Huggins, R.; Bristow, G. The survival of academic spinoff companies: An empirical study of key determinants. Int. Small Bus. J. 2019, 37, 502-535. [CrossRef]

68. Bergek, A.; Norrman, C. Incubator best practice: A framework. Technovation 2008, 28, 20-28. [CrossRef]

69. Akbar, Y.; Balboni, B.; Bortoluzzi, G.; Dikova, D.; Tracogna, A. Disentangling resource and mode escalation in the context of emerging markets. Evidence from a sample of manufacturing SMEs. J. Int. Manag. 2018, 24, 257-270. [CrossRef]

70. Guvernul României. Ordonanța nr. 8/1997 privind stimularea cercetării-dezvoltării și inovării. 1997. Available online: http://www.cdep.ro/pls/legis/legis_pck.htp_act?ida=13234 (accessed on 24 August 2019).

71. OECD. Oslo Manual. Guidelines for Collecting and Interpreting Innovation Data; OECD: Paris, France, 2005.

72. Saridakis, G.; Idris, B.; Hansen, J.M.; Dana, L.P. SMEs' internationalisation: When does innovation matter? J. Bus. Res. 2019, 96, 250-263. [CrossRef]

73. Guan, H.J.; Zhang, Z.; Zhao, A.W.; Jia, J.Y.; Guan, S. Research on Innovation Behavior and Performance of New Generation Entrepreneur Based on Grounded Theory. Sustainable (Basel) 2019, 11, 2883. [CrossRef]

74. Botezatu, M.A. Insight Into Project Risk Management. J. Inf. Syst. Oper. Manag. 2016, 10, 137-150.

75. Kitching, J. Regulatory reform as risk management: Why governments redesign micro company legal obligations. Int. Small Bus. J. 2019, 37, 395-416. [CrossRef]

76. National Institute of Statistics. Statistical Yearbooks of Romania. Available online: http://www.insse.ro/cms/ en/content/statistical-yearbooks-romania (accessed on 12 August 2019).

77. Dodgson, M. Innovation in firms. Oxf. Rev. Econ. Policy 2017, 33, 85-100. [CrossRef]

78. Gomes, G.; Wojahn, R.M. Organizational learning capability, innovation and performance: Study in small and medium-sized enterprises (SMES). Rev. Adm. 2017, 52, 163-175. [CrossRef]

79. Kosgei, C.N.; Maru, C.L. Learning orientation and innovativeness of small and micro-enterprises. Int. J. Small Bus. Entrep. Res. 2015, 3, 1-10.

80. Calantone, R.J.; Cavusgil, S.T.; Zhao, Y.S. Learning orientation, firm innovation capability, and firm performance. Ind. Mark. Manag. 2002, 31, 515-524. [CrossRef]

81. Pang, C.W.; Wang, Q.; Li, Y.; Duan, G. Integrative capability, business model innovation and performance: Contingent effect of business strategy. Eur. J. Innov. Manag. 2019, 22, 541-561. [CrossRef]

82. Ratnawati, T.; Soetjipto, B.E.; Murwani, F.D.; Wahyono, H. The Role of SMEs' Innovation and Learning Orientation in Mediating the Effect of CSR Programme on SMEs' Performance and Competitive Advantage. Glob. Bus. Rev. 2018, 19, S21-S38. [CrossRef]

83. Alegre, J.; Chiva, R. Assessing the impact of organizational learning capability on product innovation performance: An empirical test. Technovation 2008, 28, 315-326. [CrossRef] 
84. Morrison, A.; Pietrobelli, C.; Rabellotti, R. Global Value Chains and Technological Capabilities: A Framework to Study Learning and Innovation in Developing Countries. Oxf. Dev. Stud. 2008, 36, 36-58. [CrossRef]

85. Keskin, H. Market orientation, learning orientation, and innovation capabilities in SMEs. Eur. J. Innov. Manag. 2006, 9, 396-417. [CrossRef]

86. Salavou, H. Do Customer and Technology Orientations Influence Product Innovativeness in SMEs? Some New Evidence from Greece. J. Mark. Manag. 2005, 21, 307-338. [CrossRef]

87. Hou, B.J.; Hong, J.; Zhu, K.J.; Zhou, Y. Paternalistic leadership and innovation: The moderating effect of environmental dynamism. Eur. J. Innov. Manag. 2019, 22, 562-582. [CrossRef]

88. Tariq, A.; Badir, Y.; Chonglerttham, S. Green innovation and performance: Moderation analyses from Thailand. Eur. J. Innov. Manag. 2019, 22, 446-467. [CrossRef]

89. Zhao, Y.X.; Thompson, P. Investments in managerial human capital: Explanations from prospect and regulatory focus theories. Int. Small Bus. J. 2019, 37, 365-394. [CrossRef]

90. Mavondo, F.T.; Chimhanzi, J.; Stewart, J. Learning orientation and market orientation. Eur. J. Mark. 2005, 39, 1235-1263. [CrossRef]

91. Sirelli, G. Innovation and firm performance. In Proceedings of the Conference Innovation and Enterprise Creation: Statistics and Indicators, Sophia Antipolis, France, 23-24 November 2000.

92. Bacon-Gerasymenko, V. When do organisations learn from successful experiences? The case of venture capital firms. Int. Small Bus. J. 2019, 37, 450-472. [CrossRef]

93. Khosravi, P.; Newton, C.; Rezvani, A. Management innovation: A systematic review and meta-analysis of past decades of research. Eur. Manag. J. 2019, in press. [CrossRef]

94. Birkinshaw, J.; Hamel, G.; Mol, M. Management Innovation; In AIM Working Paper Series: 021-July-2005; School, L.B., Ed.; Advanced Institute of Management Research: London, UK, 2005.

95. Anzola-Roman, P.; Bayona-Saez, C.; Garcia-Marco, T. Organizational innovation, internal RandD and externally sourced innovation practices: Effects on technological innovation outcomes. J. Bus. Res. 2018, 91, 233-247. [CrossRef]

96. Botezatu, M.A.; Pirnau, C.; Carp, R.M.C. A Modern Quality Assurance System-Condition and Support to an Efficient Management. Tem J. 2019, 8, 125-131.

(C) 2020 by the authors. Licensee MDPI, Basel, Switzerland. This article is an open access article distributed under the terms and conditions of the Creative Commons Attribution (CC BY) license (http://creativecommons.org/licenses/by/4.0/). 